\title{
Front Matter: Volume 8884
}

, "Front Matter: Volume 8884," Proc. SPIE 8884, Optifab 2013, 888401 (15 October 2013); doi: 10.1117/12.2033984

SPIE. Event: SPIE Optifab, 2013, Rochester, New York, United States 


\title{
PROCEEDINGS OF SPIE
}

\section{Optifab 2013}

\author{
Julie L. Bentley \\ Matthias Pfaff \\ Editors
}

14-17 October 2013

Rochester, New York, United States

Sponsored by

SPIE

Cosponsored by

The American Precision Optics Manufacturers Association

Published by

SPIE

\section{Volume 8884}


The papers included in this volume were part of the technical conference cited on the cover and title page. Papers were selected and subject to review by the editors and conference program committee. Some conference presentations may not be available for publication. The papers published in these proceedings reflect the work and thoughts of the authors and are published herein as submitted. The publisher is not responsible for the validity of the information or for any outcomes resulting from reliance thereon.

Please use the following format to cite material from this book:

Author(s), "Title of Paper," in Optifab 2013, edited by Julie L. Bentley, Matthias Pfaff, Proceedings of SPIE Vol. 8884 (SPIE, Bellingham, WA, 2013) Article CID Number.

ISSN: 0277-786X

ISBN: 9780819497475

Published by

SPIE

P.O. Box 10, Bellingham, Washington 98227-0010 USA

Telephone +1 3606763290 (Pacific Time) · Fax +1 3606471445

SPIE.org

Copyright @ 2013 , Society of Photo-Optical Instrumentation Engineers.

Copying of material in this book for internal or personal use, or for the internal or personal use of specific clients, beyond the fair use provisions granted by the U.S. Copyright Law is authorized by SPIE subject to payment of copying fees. The Transactional Reporting Service base fee for this volume is $\$ 18.00$ per article (or portion thereof), which should be paid directly to the Copyright Clearance Center (CCC), 222 Rosewood Drive, Danvers, MA 01923. Payment may also be made electronically through CCC Online at copyright.com. Other copying for republication, resale, advertising or promotion, or any form of systematic or multiple reproduction of any material in this book is prohibited except with permission in writing from the publisher. The CCC fee code is $0277-786 \mathrm{X} / 13 / \$ 18.00$.

Printed in the United States of America.

Publication of record for individual papers is online in the SPIE Digital Library.

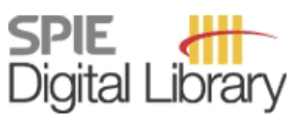

SPIEDigitalLibrary.org

Paper Numbering: Proceedings of SPIE follow an e-First publication model, with papers published first online and then in print and on CD-ROM. Papers are published as they are submitted and meet publication criteria. A unique, consistent, permanent citation identifier (CID) number is assigned to each article at the time of the first publication. Utilization of CIDs allows articles to be fully citable as soon as they are published online, and connects the same identifier to all online, print, and electronic versions of the publication. SPIE uses a six-digit CID article numbering system in which:

- The first four digits correspond to the SPIE volume number.

- The last two digits indicate publication order within the volume using a Base 36 numbering

system employing both numerals and letters. These two-number sets start with 00, 01, 02, 03, 04,

05, 06, 07, 08, 09, 0A, OB ... 0Z, followed by 10-1Z, 20-2Z, etc.

The CID Number appears on each page of the manuscript. The complete citation is used on the first page, and an abbreviated version on subsequent pages. Numbers in the index correspond to the last two digits of the six-digit CID Number. 


\section{Contents}

PLENARY PAPER

888403 NASA funding opportunities for optical fabrication and testing technology development (Plenary Paper) [8884-501]

H. P. Stahl, NASA Marshall Space Flight Ctr. (United States)

\section{GRINDING AND POLISHING PROCESSES I}

888404 Cost effective fabrication method for large sapphire sensor windows [8884-1] M. Walters, A. Gould, K. Bartlett, M. R. Brophy, J. DeGroote Nelson, Optimax Systems, Inc. (United States)

888405 Effects of varying machine stiffness and contact area in Ultraform Finishing [8884-2] D. E. Briggs, S. Echaves, B. Pidgeon, N. Travis, J. D. Ellis, Univ. of Rochester (United States)

888406 Determination of a suitable parameter field for the active fluid jet polishing process [8884-3] R. Maurer, H. Biskup, C. Trum, R. Rascher, C. Wünsche, Hochschule Deggendorf (Germany)

888407 Magnetorheological finishing with chemically modified fluids for studying material removal of single-crystal ZnS [8884-4]

S. Salzman, H. J. Romanofsky, Univ. of Rochester (United States); Y. I. Clara, Rochester Institute of Technology (United States); L. J. Giannechini, G. West, J. C. Lambropoulos, S. D. Jacobs, Univ. of Rochester (United States)

888408 Dressing of fine grained diamond grinding wheels for ultra precision grinding of structured molds in brittle hard materials [8884-5]

T. Bletek, F. Klocke, M. Hünten, O. Dambon, Fraunhofer-Institut für Produktionstechnologie (Germany)

\section{GRINDING AND POLISHING PROCESSES II}

$8884 \mathrm{OA}$ Efficiency of magnetorheological fluid finishing on the elimination of defects in fused silica optics [8884-7]

R. Catrin, D. Taroux, P. Cormont, C. Maunier, T. Corbineau, G. Razé, J. Néauport,

Commissariat à l'Énergie Atomique (France)

8884 OC Relationships between subsurface damage depth and surface roughness of grinded glass optics [8884-9]

P. Blaineau, R. Laheurte, P. Darnis, Univ. Bordeaux 1 (France); N. Darbois, Commissariat à I'Énergie Atomique (France); O. Cahuc, Univ. Bordeaux 1 (France); J. Néauport,

Commissariat à l'Énergie Atomique (France) 
8884 OE Multiwavelength digital holography for polishing tool shape measurement [8884-11] V. Lédl, Institute of Plasma Physics of the ASCR, v.v.i. (Czech Republic); P. Psota, Institute of Plasma Physics of the ASCR, v.v.i. (Czech Republic) and Technical Univ. of Liberec (Czech Republic); J. Václavík, Institute of Plasma Physics of the ASCR, v.v.i. (Czech Republic); R. Doleček, Institute of Plasma Physics of the ASCR, v.v.i. (Czech Republic) and Technical Univ. of Liberec (Czech Republic); P. Vojtíšek, Institute of Plasma Physics of the ASCR, v.v.i. (Czech Republic)

\section{GRINDING AND POLISHING PROCESSES III}

8884 OG Deterministic polishing process for aspheric lenses in a production environment [8884-13] G. Stach, F. Schwalb, Satisloh GmbH (Germany)

$8884 \mathrm{OH} \quad$ Deterministic finishing of aspheric optical components [8884-14] T. Lambropoulos, E. Fess, S. DeFisher, OptiPro Systems (United States)

$8884 \mathrm{Ol} \quad$ Efficient grinding and polishing processes for asphere manufacturing [8884-15] M. Hinn, Schneider GmbH \& Co. KG (Germany); A. Pisarski, Schneider Optical Machines Inc. (United States)

$88840 \mathrm{~J} \quad$ Getting the most out of your cerium oxide glass polishing slurry: reducing risk and improving performance with plasma produced particles [8884-16]

P. G. Murray, A. Hooper, Nanophase Technologies Corp. (United States); J. Keleher, J. Kaiser, M. Nichol, Lewis Univ. (United States)

\section{OPTICAL FABRICATION OF FREEFORM SURFACES}

$8884 \mathrm{OL}$ Developments in precision optical grinding technology [8884-18]

E. Fess, M. Bechtold, F. Wolfs, R. Bechtold, OptiPro Systems (United States)

$8884 \mathrm{OM} \quad$ Additive manufacturing of tools for lapping glass [8884-19]

W. B. Williams, The Univ. of North Carolina at Charlotte (United States)

$8884 \mathrm{ON} \quad$ Freeform polishing with UltraForm Finishing [8884-20]

F. Wolfs, E. Fess, S. DeFisher, OptiPro Systems (United States)

$888400 \quad$ Fabricating freeform multispectral-ZnS corrector lenses [8884-21]

M. R. Brophy, N. Smith, T. Hordin, A. Gould, K. Medicus, M. Walters, J. DeGroote Nelson, Optimax Systems, Inc. (United States)

8884 OP Integrated manufacturing of complex freeform surfaces [8884-23] F. Niehaus, S. Huttenhuis, Schneider GmbH \& Co. KG (Germany); A. Pisarski, Schneider Optical Machines Inc. (United States)

$8884 \mathrm{OQ}$ Efficient machining of ultra precise steel moulds with freeform surfaces [8884-22] B. Bulla, son-x Gmbh (Germany); D. J. Robertson, Durham Univ. (United Kingdom); O. Dambon, F. Klocke, Fraunhofer-Institut für Produktionstechnologie (Germany) 
8884 OR Conformal window manufacturing process development and demonstration for polycrystalline materials [8884-24]

N. E. Smith, A. R. Gould, T. Hordin, K. Medicus, M. Walters, M. Brophy, J. DeGroote Nelson, Optimax Systems, Inc. (United States)

8884 OS Fabrication of high precision metallic freeform mirrors with magnetorheological finishing (MRF) [8884-91]

M. Beier, S. Scheiding, Fraunhofer-Institut für Angewandte Optik und Feinmechanik (Germany) and Friedrich-Schiller-Univ. Jena (Germany); A. Gebhardt, R. Loose, S. Risse, R. Eberhardt, Fraunhofer-Institut für Angewandte Optik und Feinmechanik (Germany); A. Tünnermann, Fraunhofer-Institut für Angewandte Optik und Feinmechanik (Germany) and Friedrich-Schiller-Univ. Jena (Germany)

METROLOGY I

8884 OT Comparison of alignment errors in asphere metrology between an interferometric null-test measurement and a non-null measurement with the tilted-wave-interferometer [8884-25] G. Baer, J. Schindler, C. Pruss, W. Osten, Univ. Stuttgart (Germany)

$8884 \mathrm{OU}$ Comparison of contact and non-contact asphere surface metrology devices [8884-26] S. DeFisher, E. M. Fess, OptiPro Systems (United States)

8884 OV Non-contact metrology of aspheric surfaces based on MWLI technology [8884-27] G. Berger, J. Petter, Luphos GmbH (Germany)

8884 OW Vertical interferometer workstation for testing large spherical optics [8884-28] B. Truax, Zygo Corp. (United States)

8884 OX Retrace error: interferometry's dark little secret [8884-29]

C. B. Kreischer, Kreischer Optics, Ltd. (United States)

8884 OY Round-robin measurements of toroidal window [8884-30] K. Medicus, Optimax Systems, Inc. (United States); S. DeFisher, OptiPro Systems (United States); M. Bauza, Carl Zeiss Industrial Metrology LLC (United States); P. Dumas, QED Technologies, Inc. (United States)

$8884 \mathrm{OZ}$ Improved averaging for non-null interferometry [8884-31] J. F. Fleig, P. E. Murphy, QED Technologies, Inc. (United States)

888410 Development of a high-speed nanoprofiler using normal vector tracing method for highaccuracy mirrors [8884-32]

K. Okuda, T. Kitayama, K. Usuki, T. Kojima, K. Okita, J. Uchikoshi, Osaka Univ. (Japan); Y. Higashi, High Energy Accelerator Research Organization (Japan); K. Endo, Osaka Univ. (Japan) 
888411 Fabrication and metrology of high-precision freeform surfaces [8884-34]

C. Supranowitz, P. Dumas, T. Nitzsche, QED Technologies, Inc. (United States);

J. DeGroote Nelson, B. Light, K. Medicus, N. Smith, Optimax Systems, Inc. (United States)

888412 A simple procedure to include a free-form measurement capability to standard coordinate measurement machines [8884-35]

F. Schneider, Hochschule Deggendorf (Germany) and Univ. of the West of England (United Kingdom); R. Rascher, Hochschule Deggendorf (Germany); R. Stamp, G. Smith, Univ. of the West of England (United Kingdom)

888413 3D-form metrology of arbitrary optical surfaces by absorption in fluids [8884-36]

J. C. Martínez Antón, J. M. Plaza Ortega, J. Alonso, Univ. Complutense de Madrid (Spain)

888414 Worthwhile optical method for free-form mirrors qualification [8884-37]

G. Sironi, R. Canestrari, INAF - Osservatorio Astronomico di Brera (Italy); G. Toso, INAF - IASF

Milano (Italy); G. Pareschi, INAF - Osservatorio Astronomico di Brera (Italy)

\section{OPTICAL MATERIALS, CLEANING, AND COATING}

888416 Characterization of structural relaxation in $\mathrm{As}_{2} \mathrm{Se}_{3}$ for analysis of lens shape change in glass press mold cooling and post-process annealing [8884-38]

E. Koontz, P. Wachtel, CREOL, The College of Optics and Photonics, Univ. of Central Florida (United States) and Clemson Univ. (United States); J. D. Musgraves, CREOL, The College of Optics and Photonics, Univ. of Central Florida (United States), Clemson Univ. (United States), and IRradiance Glass, Inc. (United States); K. Richardson, CREOL, The College of Optics and Photonics, Univ. of Central Florida (United States) and Clemson Univ. (United States)

888417 Compositional-tailoring of optical properties in IR transparent chalcogenide glasses for precision glass molding [8884-39]

B. Gleason, P. Wachtel, CREOL, The College of Optics and Photonics, Univ. of Central Florida (United States) and Clemson Univ. (United States); J. D. Musgraves, CREOL, The College of Optics and Photonics, Univ. of Central Florida (United States), Clemson Univ. (United States), and IRradiance Glass, Inc. (United States); A. Qiao, N. Anheier, Pacific Northwest National Lab. (United States); K. Richardson, CREOL, The College of Optics and Photonics, Univ. of Central Florida (United States) and Clemson Univ. (United States)

888419 SP-100 the fast and reliable machine for coating application in precision optics [8884-41]

G. Monaco, Satisloh Italy S.r.l. (Italy); M. Peter, Satisloh Photonics AG (Switzerland);

A. Colautti, Satisloh Italy S.r.l. (Italy); T. Godin, Satisloh North America Inc. (United States); S. Gold, Satisloh GmbH (Germany); M. Witzany, Satisloh Italy S.r.l. (Italy) and Satisloh GmbH (Germany); F. Breme, Satisloh Photonics AG (Switzerland)

8884 1A Development of a high specification coating [8884-42]

P. E. MacKay, M. Wilde, Gooch \& Housego Ltd. (United Kingdom) 
8884 IB Refractive index of thin films realized by Satisloh SP reactive sputtering system [8884-43] G. Monaco, A. Colautti, C. Allegro, Satisloh Italy S.r.l. (Italy); T. Godin, Satisloh North America Inc. (United States); S. Gold, Satisloh GmbH (Germany); M. Witzany, Satisloh Italy S.r.l. (Italy) and Satisloh GmbH (Germany)

\section{OPTICAL DESIGN}

8884 1C Optical design with orthogonal surface descriptions [8884-44]

G. W. Forbes, QED Technologies, Inc. (United States); C. Menke, Carl Zeiss AG (Germany)

8884 ID Design of systems involving easily measurable aspheres [8884-45]

P. E. Murphy, QED Technologies, Inc. (United States); D. Stephenson, JENOPTIK Optical

Systems (United States); A. E. W. Jones, G. W. Forbes, QED Technologies, Inc. (United States)

8884 lE Using Microsoft Excel as a pre-processor for CODE V optimization of air spaces when building camera lenses [8884-46]

D. Stephenson, JENOPTIK Optical Systems (United States)

$8884 \mathrm{lF}$ Integration of measurement data in the comprehensive modelling approach [8884-47] I. Sieber, Karlsruher Institut für Technologie (Germany); O. Rübenach, INGENERIC GmbH (Germany)

8884 IG Rapid design of LED optical elements with two free-form surfaces generating uniformly illuminated rectangular area [8884-48]

M. A. Moiseev, L. L. Doskolovich, S. V. Kravchenko, Image Processing Systems Institute (Russian Federation)

$8884 \mathrm{lH}$ Design of freeform optical elements generating a line-shaped directivity diagram [8884-49] L. L. Doskolovich, A. Y. Dmitriev, M. A. Moiseev, Image Processing Systems Institute (Russian Federation)

\section{OPTICAL ENGINEERING}

888411 Optical characterization of window materials for aerospace applications [8884-50] K. K. Tedjojuwono, N. Clark, W. M. Humphreys Jr., NASA Langley Research Ctr. (United States)

$88841 \mathrm{~J}$ Development of a calibration standard for spherical aberration [8884-51]

D. C. Compertore, F. V. Ignatovich, M. E. Herbrand, M. A. Marcus, Lumetrics, Inc. (United States)

$8884 \mathrm{lL}$ Precision interferometric measurements of refractive index of polymers in air and liquid [8884-53]

M. A. Marcus, K. J. Hadcock, D. S. Gibson, M. E. Herbrand, F. V. Ignatovich, Lumetrics, Inc. (United States) 
$88841 \mathrm{M}$ Optical test bench for high precision metrology and alignment of zoom sub-assembly components [8884-54]

F. Leprêtre, E. Levillain, Thales Angénieux S.A. (France); B. Wattellier, P. Delage, D. Brahmi,

A. Gascon, PHASICS S.A. (France)

METER CLASS OPTICS

8884 IN Low weight mirror substrates [8884-55]

P. E. MacKay, Gooch \& Housego Ltd. (United Kingdom); N. L. Beveridge, Gooch \& Housego Ltd. (United Kingdom) and Univ. of Glasgow (United Kingdom); T. Wood, Surrey Satellite Technology Ltd. (United Kingdom)

8884 IP Model-based polishing of meter size optics [8884-57]

J.-C. Kupfer, M. Achtsnick, E. Becker, Berliner Glas KGaA Herbert Kubatz GmbH \& Co. (Germany)

$8884 \mathrm{lQ}$ Slumping technique for the manufacturing of a representative $\mathrm{x}$-ray grazing incidence mirror module for future space missions [8884-58]

M. Ghigo, INAF - Osservatorio Astronomico di Brera (Italy); L. Proserpio, INAF - Osservatorio Astronomico di Brera (Italy) and Max-Planck-Institut für extraterrestrische Physik (Germany); S. Basso, O. Citterio, M. M. Civitani, G. Pareschi, B. Salmaso, G. Sironi, D. Spiga,

G. Tagliaferri, G. Vecchi, A. Zambra, INAF - Osservatorio Astronomico di Brera (Italy); G. Parodi, F. Martelli, BCV Progetti S.r.I. (Italy); D. Gallieni, M. Tintori, A.D.S. International S.r.I. (Italy); M. Bavdaz, E. Wille, European Space Research and Technology Ctr. (Netherlands); I. Ferrario, Media Lario Technologies S.r.I. (Italy); V. Burwitz, Max-Planck-Institut für extraterrestrische Physik (Germany)

8884 IR Thin monolithic glass shells for future high angular resolution and large collecting area $\mathrm{X}$-ray telescope [8884-59]

M. M. Civitani, O. Citterio, M. Ghigo, INAF - Osservatorio Astronomico di Brera (Italy); E. Mattaini, INAF - Osservatorio Astronomico di Brera (Italy) and INAF - IASF Milano (Italy); G. Pareschi, INAF - Osservatorio Astronomico di Brera (Italy); G. Parodi, BCV Progetti S.r.I. (Italy)

8884 is Effect of polishing plane vibration on large-size optical workpieces in continuous polishing [8884-60]

$\mathrm{H}$. Shan, Shanghai Institute of Optics and Fine Mechanics (China) and Univ. Of Chinese Academy of Sciences (China); C. Wei, X. XU, H. He, S. Liu, Y. Li, K. Yi, J. Shao, Shanghai Institute of Optics and Fine Mechanics (China) 
8884 IT Nanoscale optical features via hot-stamping of $\mathrm{As}_{2} \mathrm{Se}_{3}$ glass [8884-61]

S. Danto, E. Koontz, CREOL, The College of Optics and Photonics, Univ. of Central Florida (United States) and Clemson Univ. (United States); Y. Zou, T. O. Ogbuu, Univ. of Delaware (United States); B. Gleason, P. Wachtel, CREOL, The College of Optics and Photonics, Univ. of Central Florida (United States) and Clemson Univ. (United States); J. D. Musgraves, CREOL, The College of Optics and Photonics, Univ. of Central Florida (United States), Clemson Univ. (United States), and IRradiance Glass, Inc. (United States); J. Hu, Univ. of Delaware (United States); K. Richardson, CREOL, The College of Optics and Photonics, Univ. of Central Florida (United States) and Clemson Univ. (United States)

$88841 \mathrm{U}$ Chalcogenide-mold interactions during precision glass molding (PGM) of GeAsSe glasses [8884-62]

B. Gleason, P. Wachtel, CREOL, The College of Optics and Photonics, Univ. of Central Florida (United States) and Clemson Univ. (United States); J. D. Musgraves, CREOL, The College of Optics and Photonics, Univ. of Central Florida (United States), Clemson Univ. (United States), and IRradiance Glass, Inc. (United States); R. Steinkopf, R. Eberhardt, Fraunhofer-Institut für Angewandte Optik und Feinmechanik (Germany); K. Richardson, CREOL, The College of Optics and Photonics, Univ. of Central Florida (United States), Clemson Univ. (United States), and IRradiance Glass, Inc. (United States)

8884 IV Novel testing facility for investigating wear on PGM sample tools [8884-64]

F. Bernhardt, K. Georgiadis, O. Dambon, F. Klocke, Fraunhofer-Institut für Produktionstechnologie (Germany)

$8884 \mathrm{IW}$ Melt spun aluminium alloys for moulding optics [8884-65]

G. Gubbels, RSP Technology (Netherlands); L. Tegelaers, Oerlikon Balzers Coating Benelux N.V. (Belgium); R. Senden, RSP Technology (Netherlands)

$88841 \mathrm{X}$ Shaping of thin glass foils for the fabrication of mirrors with pronounced asphericity [8884-66]

R. Canestrari, G. Pareschi, G. Sironi, INAF - Osservatorio Astronomico di Brera (Italy); G. Toso, INAF - IASF Milano (Italy)

8884 IY Interaction of N-FK5 and L-BAL35 optical glass with various carbide and other precision glass mold tooling [8884-90]

E. Koontz, CREOL, The College of Optics and Photonics, Univ. of Central Florida (United States) and Clemson Univ. (United States); P. Wachtel, Clemson Univ. (United States); J. D. Musgraves, CREOL, The College of Optics and Photonics, Univ. of Central Florida (United States), Clemson Univ. (United States), and IRradiance Glass, Inc. (United States); K. Richardson, CREOL, The College of Optics and Photonics, Univ. of Central Florida (United States) and Clemson Univ. (United States); S. Mourad, M. Huber, A. Kunz, M. Forrer, FISBA OPTIK AG (Switzerland)

POSTER SESSION

888420 Properties of Kummer beams in the structure of metamaterials [8884-69]

M. Marín-Suárez, Univ. EAFIT (Colombia) 
888422 Simulations and first manufacturing steps of a fully integrated WDM-element in the visible spectrum [8884-71]

S. Höll, M. Haupt, U. H. P. Fischer, Hochschule Harz (Germany)

888423 Off-axis mirror fabrication from spherical surfaces under mechanical stress [8884-72]

R. Izazaga-Pérez, D. Aguirre-Aguirre, M. E. Percino-Zacarías, F. S. Granados-Agustín, Instituto Nacional de Astrofísica, Óptica y Electrónica (Mexico)

888427 4D phase profile measurements using a single-shot phase shifting technique [8884-77] N.-I. Toto-Arellano, Univ. Tecnológica de Tulancingo (Mexico); A. Montes-Pérez, A. Martínez García, D. Serrano-García, Ctr. de Investigaciones en Óptica, A.C. (Mexico); L. R. Castelán Olvera, J. Martínez Lozano, A. Jorge Muñoz, Univ. Tecnológica de Tulancingo (Mexico)

888428 Wavefront measurements through optical diffraction interpretation [8884-80]

S. Bouillet, S. Chico, L. Eupherte, C. Rouyer, J. Daurios, Commissariat à l'Énergie Atomique (France)

888429 Absolute testing of freeform lens [8884-81]

X. Jia, T. Xing, Institute of Optics and Electronics (China)

$88842 \mathrm{~B} \quad$ Fabrication of solid immersion lens applied to infrared microscopy to improve the spatial resolution over its diffraction limit [8884-84]

H. Sung, Korea Basic Science Institute (Korea, Republic of) and Chungnam National Univ. (Korea, Republic of); M. S. Huh, Osong Medical Innovation Foundation (Korea, Republic of); G. J. Lee, K. Lee, Korea Basic Science Institute (Korea, Republic of); Y. Kim, College of Optical Sciences, The Univ. of Arizona (United States); G. Ryu, Korea Basic Science Institute (Korea, Republic of) and Chungnam National Univ. (Korea, Republic of); S. C. Yang, Osong Medical Innovation Foundation (Korea, Republic of); K.-J. Yee, C. Park, Chungnam National Univ. (Korea, Republic of); G. Kim, Korea Basic Science Institute (Korea, Republic of) and Chungnam National Univ. (Korea, Republic of)

8884 2C Slope-sensitive optical probe for freeform optics metrology [8884-85]

M. A. Echter, A. D. Keene, C. D. Roll, J. D. Ellis, Univ. of Rochester (United States)

$88842 \mathrm{E} \quad$ Smart and precise alignment of optical systems [8884-88]

P. Langehanenberg, J. Heinisch, D. Stickler, TRIOPTICS GmbH (Germany)

$88842 \mathrm{~F} \quad$ OptiCentric lathe centering machine [8884-89]

C. BUß, J. Heinisch, TRIOPTICS GmbH (Germany)

$88842 \mathrm{G}$ Hexapods with fieldbus interfaces for automated manufacturing of opto-mechanical components [8884-95]

S. Schreiber, C. Muellerleile, M. Frietsch, R. Gloess, Physik Instrumente (PI) GmbH \& Co. KG (Germany)

$88842 \mathrm{H} \quad$ Experimental study on SPDT machining of Gallium Phosphide [8884-92]

J. Vaclavík, R. Doleček, V. Lédl, P. Psota, Institute of Plasma Physics of the ASCR, v.v.i.

(Czech Republic) 
$888421 \quad$ Improved MRF spot characterization with QIS metrology [8884-94]

S. Westover, Univ. of Rochester (United States); C. Hall, M. DeMarco, QED Technologies, Inc. (United States)

Author Index

Proc. of SPIE Vol. $8884888401-11$

Downloaded From: https://www.spiedigitallibrary.org/conference-proceedings-of-spie on 26 Apr 2023 Terms of Use: https://www.spiedigitallibrary.org/terms-of-use 


\title{
Conference Committee
}

\author{
Symposium Chairs
}

Julie L. Bentley, University of Rochester (United States)

Matthias Pfaff, OptoTech Optikmaschinen GmbH (Germany)

Conference Chairs

Julie L. Bentley, University of Rochester (United States)

Matthias Pfaff, OptoTech Optikmaschinen GmbH (Germany)

\section{Conference Program Committee}

Thomas Battley, New York Photonics Industry Association (United States)

Michael J. Bechtold, OptiPro Systems (United States)

Christopher T. Cotton, ASE Optics (United States)

Walter C. Czajkowski, Edmund Optics, Inc. (United States)

Thomas Danger, Schneider GmbH \& Company KG (Germany)

Michael A. DeMarco, QED Technologies, Inc. (United States)

Apostolos Deslis, JENOPTIK Optical Systems, Inc. (United States)

Toshihide Dohi, OptiWorks, Inc. (Japan)

Tom Godin, Satisloh North America Inc. (United States)

Heidi Hofke, OptoTech Optical Machinery Inc. (United States)

Jay Kumler, JENOPTIK Optical Systems, Inc. (United States)

Justin J. Mahanna, Universal Photonics Inc. (United States)

Michael A. Marcus, Lumetrics (United States)

Paul Meier-Wang, AccuCoat Inc. (United States)

Ted Mooney, ITT Exelis (United States)

Richard A. Nasca, Corning Tropel Corporation (United States)

Michael N. Naselaris, Sydor Optics, Inc. (United States)

John J. Nemechek, Metrology Concepts LLC (United States)

Buzz Nesti, Naked Optics Corporation (United States)

Robert F. Novak, BAN Optical (United States)

Paul R. Tolley, Smart System Technology \& Commercialization Center

(United States)

Martin J. Valente, Arizona Optical Systems, LLC (United States)

Kirk J. Warden, LaCroix Optical Company (United States)

Robert Anton Wiederhold, Optimax Systems, Inc. (United States)

Session Chairs

1 Grinding and Polishing Processes I

Matthias Pfaff, OptoTech Optikmaschinen GmbH (Germany) 
2 Grinding and Polishing Processes II

Jessica E. DeGroote Nelson, Optimax Systems, Inc. (United States)

3 Grinding and Polishing Processes III

Michael J. Bechtold, OptiPro Systems (United States)

4 Optical Fabrication of Freeform Surfaces

Jonathan D. Ellis, University of Rochester (United States)

5 Metrology I

Paul Dumas, QED Technologies, Inc. (United States)

6 Plenary Session I

Julie L. Bentley, University of Rochester (United States)

7 Metrology II

Kate Medicus, Optimax Systems, Inc. (United States)

8 Optical Materials, Cleaning, and Coating

Dave Stephenson, JENOPTIK Optical Systems (United States)

9 Optical Design

Theodore Tienvieri, Corning Tropel Corporation (United States)

10 Optical Engineering

Christopher T. Cotton, ASE Optics (United States)

11 Plenary Session II

Julie L. Bentley, University of Rochester (United States)

12 Meter Class Optics

Ted Mooney, ITT Exelis (United States)

13 Molded Optics

Michael A. Marcus, Lumetrics, Inc. (United States) 